\title{
Service - Oriented Challenges for Design Science: Charting the "E"-volution
}

\author{
Hong-Mei Chen \\ Shidler College of Business \\ University of Hawaii at Manoa \\ hmchen@hawaii.edu \\ Stephen L. Vargo \\ University of Hawaii at Manoa \\ svargo@hawaii.edu
}

\begin{abstract}
This article links service-dominant (S-D) logic and design science to advance service system design, which is characterized by the indeterminacy of the design problems and outcome measures. Although much progress has been made in IT and IS toward service-orientation, these developments are often adaptations of goods-dominant (G-D) logic, rather than a full transition to a service orientation. In this paper, the "e"-volution of systems design, transitioning from G-D logic to S-D logic, is described and the IS design challenges implied by S-D logic are identified. To devise new, service-oriented modeling, methods and evaluation measurements, $S-D$ logic endorses a fundamental shift in design thinking for design science from "bounded rationality" for problem solving to "expandable rationality" for design for the unknown.
\end{abstract}

Keywords : Service Dominant Logic, Service-Oriented IS design, Information System Research, Design Thinking, Design Science, Service Systems, Effectual Logic, Transformative Design, Expandable Rationality, Adaptive Design. 


\section{Introduction}

The global economy is going through a radical transformation from a goods focus to a service focus, often characterized as a shift from a manufacturing economy to a service(s) economy, especially among developed countries. In IT, this transformation is reflected in a near tsunami of service-related technologies and initiatives such as softwareas-a- service (SaaS), infrastructure-as- a service (laaS), platform-as-a-service (PaaS), service grid, web services, service-oriented architecture (SOA), service computing, selfservice, and IT service management. More generally, it has led to moving service(s) more centrally into academic focus, as seen in research initiatives such as "servitization," the understanding of goods-services bundles, and service science, the study of service systems (Maglio and Spohrer, 2008), to rethinking the approaches to innovation as seen through design science and service design.

Alternatively, or in addition to, it has been suggested that there is an even more foundational shift taking place, one from a logic of business and economic exchange being primarily concerned with goods goods-dominant (G-D) logic -- to a logic based on the primacy of service-for-service exchange - service-dominant (S-D) logic (Vargo and Lusch 2004; 2008). This more fundamental shift has sometimes-subtle but profound implications for how we conceptualize IT-enabled service initiatives and how we approach system design, especially the meaning of and approach to innovation. The purpose of this paper is to explore these implications for Information Systems (IS).

As a discipline, IS is primarily concerned with the design (including engineering, building and evaluating) of a subset of service systems - information systems, which represent a confluence of people, process and technology. The guiding models for the design activities have, as a group, become known as "design science" which has a strong root in engineering and is fundamentally a problem-solving paradigm based on "bounded rationality" (Hevner et.al. 2004). But, arguably, design science remains at least partially rooted in G-D logic. Thus, perhaps the way we think about system design also needs to change. That is, system design is shifting from a focus on conceptualizing and building better (e.g., more value-added) output based on deterministic assumptions about design problems and solutions space to conceptualizing and co-creating better valueco-creating systems that may open new possibilities to innovation embracing indeterminacy in the design problems and outcomes. In other words, S-D logic points to a transformative design approach for IS researchers, expanding the root thinking of design science from "bounded rationality" (good enough from a knowable set) (Simon,1996), to "expandable rationality" (good enough from an unknowable set) (Hatchuel 2002; Hatchuel and Weil, 2009) and beyond (good enough from the interaction of knowable set and unknowable set). As will be discussed, this latter orientation is similar to "effectual" design recently discussed in the entrepreneurship literature (e.g., Sarasvathy 2008a; 2008b).

To explore this transformation, this article proceeds as follows. In the next section, we distinguish between G-D logic and S-D logic. In Section 3, we discuss the G-D logicinfluenced IS practice in the past and current evolution toward S-D logic, although the shift is incomplete. We use the electronic Customer Relationship Management (CRM) system design and Supply Chain Management (SCM) systems as examples to illustrate how the underlying design models based on G-D logic is inadequate. In Section 4 , we outline the IS design challenges implied by S-D logic. In section 5, we discuss the implication of S-D logic on design science. Expandable rationality of design thinking and transformative design approach for innovation is suggested. Section 6 summarizes the contribution of this article and remarks regarding "e"-novation in service system design by shifting to S-D logic. 


\section{Goods-Dominant vs. Service- Dominant Logic}

There are two perspectives for the consideration of service(s). One perspective views goods (tangible outputs embedded with value) as the primary focus of economic exchange and "services" (usually plural) as either (1) a restricted type of (intangible) good or (2) an add-on that enhances the value of a good. Vargo and Lusch $(2004 ; 2008)$ call this logic goods-dominant (G-D) logic. Others have referred to it as the "neoclassical economics research tradition" (Hunt, 2004), "manufacturing logic" (Normann 2001), "old enterprise logic" (Zuboff and Mazmin, 2002), and "marketing management" (Webster, 1992). Regardless of the label, G-D logic points toward using principles developed to manage goods production to manage services and relationship "production" and "delivery." This perspective implies that goods production and distribution practices should be modified to deal with the differences between tangible goods and services.

The second perspective of exchange and marketing considers "service" (singular) - a process of doing something for another party - in its own right, without reference to goods, and identifies service as the primary focus of exchange activity. Vargo and Lusch

$(2004 ; 2008)$ call this logic service-dominant (S-D) logic. S-D logic is captured in the following 10 foundational premises (FPs) (Vargo and Lusch, 2004; 2006; 2008):

FP 1: Service is the fundamental basis of exchange. The application of operant resources (knowledge and skills), "service," as defined in S-D logic, is the basis for all exchange. Service is exchanged for service.

FP 2: Indirect exchange masks the fundamental basis of exchange. Because service is provided through complex combinations of goods, money, and institutions, the service basis of exchange is not always apparent.

FP 3: Operant resources are the fundamental source of competitive advantage.
The comparative ability to cause desired change drives competition.

FP 4: Goods are a distribution mechanism for service provision. Goods (both durable and non-durable) derive their value through use the service they provide.

FP 5: All economies are service economies. Service (singular). This is only now becoming more apparent with increased specialization and outsourcing

FP 6: The customer is always a co-creator of value. This implies value creation is interactional.

FP 7: The enterprise cannot deliver value, but only offer value propositions.

Enterprises can offer their applied resources for value creation and collaboratively (interactively) create value following acceptance of value propositions, but cannot create and/or deliver value independently

FP 8: A service-centered view is inherently customer oriented and relational. Because service is defined in terms of customerdetermined benefit and co-created, it is inherently customer oriented and relational.

FP 9: All social and economic actors are resource integrators. This implies the context of value creation is networks of networks (resource integrators).

FP10: Value is always uniquely and phenomenologically determined by the beneficiary. Value is idiosyncratic, experiential, contextual, and meaning laden.

Instead of seeing "services" (plural) as what products are not, the concept of "service" (singular) foregrounds the application of one's resources for the benefit of another. S-D logic superordinates service to products (units of tangible or intangible output-goods (and "services"), which are only sometimes used in the process.

In S-D logic, goods continue to play an important service-delivery role, at least in a subset of economic exchange, but the fundamental exchange is service-for-service in a dynamic process. In contrast to implying 
the modification of goods-based models of exchange to fit a transition to service, S-D logic provides a service-based foundation based upon service-driven principles.

The S-D logic perspective on service stresses "value-in-use" (rather than traditional, economics and G-D logic model of "value-inexchange") and "value-in-context" (Vargo and Lusch 2008) and shifts the focus on the process of value co-creation with customers: activity that is fundamentally directed at seeking and providing solutions. The idea of the customer as a co-creator of value is tied to the identification of all parties as resources integrators. It points to a network-with (and within)-network conceptualization of relationships that converge on value creation through a web of resource integration. Instead of value being embedded in objects through a value chain, value is created through exchanges of service in value-cocreation systems - service system (Maglio and Spohrer, 2008). In this view, the "service economy" is not new; all economies are service economies.

\section{System Design Transitioning from G-D logic to S-D logic}

The S-D Logic perspective on service has subtle yet profound implication for information systems and their design. In this section, we first define service system and clarify that information system is a special type of service system. The first implication is that service orientation is critical for IS success. We then examine the effect of G-D logic on information system design. We suggest that the failures of information system development can be partially attributed to the G-D logic orientation using two critical enterprise information systems, CRM and SCM, as examples. We then discuss the central concept of S-D, the dynamic value network, as the new IS design context.

Service systems are value-creation networks composed of people, technology, and organizations (Maglio et.al., 2006) Specifically, they are "dynamic value cocreation configuration of resources, including people, organizations, shared information (language, laws, measures, methods), and technology, all connected internally and externally to other service systems by value propositions." (Maglio and Spohrer, 2008) According to this broad, scalable definition, a person or a service-providing organization of any size can be seen as a service system.

An information system is a distinct type of service system, an IT artifact designed and created to "solve identified organizational problems" (Hevner et. al. 2004). "Information systems are implemented within an organization for the purpose of improving the effectiveness and efficiency of that organization." (Hevner et. al. 2004) It's at the confluence of people, technology and organization. Checkland and Howell (1998/2005) describe information systems as a type of "soft system" that has to be seen as a service system: one which serves those taking the action. They suggest that IS design must start by carefully defining the action to be served, in its specific context, and using that definition to decide what information is needed and how technology will help provide it.

Furthermore, in IS, many use "service system" to describe a special type of information systems, meaning "serviceoriented information system" to emphasize explicitly the service orientation, customercentricity of the information system as opposed to other types that lack of serviceorientation. Some use "IT-enabled service system" to distinguish information systems from other types of service or serviceoriented systems.

From a G-D logic perspective, value was something embedded in goods through the manufacturing process, and early IS scholars focused on the issue of the types and extent of the utilities or "value-added" functions that a system can offer. The G-D logic view of value also led the design of the systems to be internally focused, excluding customers and their network. Likewise, the G-D logic view provides a narrow organizational context and narrow enterprise role in service provision 
and it leads to narrow view of the IS role and has limited its design This G-D logic underlies the traditional design thinking of design science paradigm: product, utility focus and deterministic problem-solving orientation. As such, traditional models of IS have championed a view of IT artifacts as productivity tools (Sameh and Benbasat, 2009). Although recently IS or IT artifacts are recognized to assume new roles beyond solely enhancing productivity, it requires good design, away from G-D logic, which holds the key to the extension of current or unforeseen new roles.

We suggest that the effective design of service systems in today's context requires a shift from the G-D logic based design thinking to $S-D$ thinking in that the enterprises must first realize that they can only offer value propositions - there is no such assumed, embedded value in products or services -and the system must be designed to focus on value co-creation and value-in-use and valuein-context for effective service provision. Instead of treating customers as outside, external entities and units of "transaction" or production, the system design should focus on interaction of co-value creation and relationship building with customers as well as other partners in the value network. In what follows, we will show that the strong hold of G-D logic on the design of critical enterprise service systems such as CRM and SCM has led to failure of many of these systems and the shift to S-D logic has been incomplete.

\section{CRM Systems}

CRM, currently a fixture in many enterprises, was intended to be a customer-centric, service-oriented information system since its conception in late 1990s. Many businesses regard CRM as a core strategic initiative for profitable competition (Chen and Chen, 2004). The premise of CRM is that customer equity is the key to increasing enterprise value and customer equity is a partial function of customer relationships. Many CRM initiatives failed (Kale, 2004; Payne and Frow, 2005). We suggest that a key reason for CRM failure is the G-D logic trap that views CRM narrowly as a technology initiative to be used in conjunction with a tactical, rather than strategic, implementation (Hart, 2006; Payne and Frow, 2005). That is, in G-D logic, services are intangible units of output and relationships are defined in terms of repetition in selling these units to a given customer (Vargo 2009). Thus, CRM based on G-D logic becomes more of an operation-centric, transaction-based, efficiency "machine" to process "customers" as "goods." This G-D logic perspective predictably leads to relatively superficial attempts at a "relationship" such as addressing people by name, personalizing written communications, and cross selling, which, while a step beyond mass-marketing, fall short of true relationship building. Thus, while these activities sometimes lead to convenience-based repeat purchases, they often do not build emotional loyalty with customers based on more effective value co-creation. Sisodia and Wolfe, (2000, p. 560) argue that, often, CRM like database marketing, is used for "little more than manipulation of consumer data in ways intended to create an illusion that the provider is presenting a customized response to an individual consumer's needs [and] is fundamentally an inauthentic play for a consumer's attention". S-D logic calls for a genuine reconnection to the original roots of CRM, focusing on the " $\mathrm{C}$ "-Customer-and the "R" - Relationship.

\section{SCM system}

Another service system that the enterprise depends on as a strategic initiative to serve customers is SCM system. A supply chain is a set of organizations directly linked by one or more of the upstream and downstream flows of products, "services," finances, and information from a source to a customer (Mentzer et. al., 2001). SCM is intended to encompass the planning and management of all activities involved in sourcing, procurement, conversion, and logistics management. It also includes the crucial components of coordination and collaboration with channel partners, which can be suppliers, intermediaries, third-party service providers, 
and customers. In essence, supply chain management intends to integrate supply and demand management within and across companies. Initial SCM systems were following the development of Electronic Data Interchange (EDI) systems in back in the 1960s and developed through the 1990s by the introduction of Enterprise Resource Planning (ERP) systems and later with the expansion of internet-based collaborative systems.

SCM design can also be seen as hijacked by G-D logic: the focus has been on "supply" -the attention was paying to more to costreduction, "adding" value, rather than true collaboration or value-cocreation with the partners or customers in the "chain." The value-added perspective suggests that value is embedded in the firm's output and is thus independent of the customer's perceptions of value. SCM design has been a victim of the G-D logic perspective because the reciprocal relationship perspective in service is difficult to integrate into or absent in the design of primarily moving the "supply" or "goods" in a production chain. S-D logic argues that it is the service, including the flow of service from appliances (good) that matters rather than (goods) possession per se.

S-D logic uses the concept of "value network," sometimes referred to as a "service ecosystem," to broaden the goods-oriented supply chain concept (Lusch, Vargo, and Tanniru, 2010; Vargo and Lusch 2011). A value network is defined as a spontaneously sensing and responding spatial and temporal structure of largely loosely coupled value proposing social and economic actors interacting through institutions and technology, to: (1) co-produce service offerings, (2) exchange service offerings, and (3) co-create value. (Lusch, Vargo, and Tanniru, 2010). Each company's supply chain is a sub-part of the value network, embedded within more value networks.

S-D logic suggests that the social and economic actors of a value network are held together by the trinity of competences, relationships, and information. A value network has structural integrity because each organization (economic and social actor) has competences (used to offer and provide service to others), relationships (with customers and suppliers-output and input relationships and governance), and information that is shared through common standards and protocols (Lusch, Vargo, and Tanniru, 2010). Value propositions are then used to connect the firm with its suppliers and customers. Importantly, once the entire value-creation network (including "customers" and customer networks) is seen as a system of mutual value creation through reciprocal, enabling and relieving service provision, all links (including with a firm's own "suppliers" and "customers") in the network represents opportunities for innovation through assisting the parties in their own value-creation activities. This is the new design context.

In sum, CRM and SCM systems discussed above are good examples of today's systems that are in need of shifting completely to S-D logic based design. As shown, the shift to service orientation (relationship intended in CRM and collaborative value co-creation intended in SCM) is only partial. Similarly, "servitization," which refers to a product with a service component, continues to reflect a G-D perspective of "services" as add-ons to goods. IT advances the delivery models of their products such as SaaS, laaS, PaaS, but these delivery models in and by themselves are not "service" provision in the S-D logic perspective, but rather production of intangible goods. SOA and web services provides computing "services" (or capabilities), which are defined as a selfcontained, distributed component with a published interface that supports interoperability, is discoverable, and is dynamically bound - this is very different from the S-D perspective of service (Chen, 2008; Chen et. al. 2010). We argue that SOA, web services, and similar technologically driven "service systems" will not reflect a true service orientation until the service-provision principles of S-D logic are incorporated in the design. Unfortunately, many system designs adopting advanced technology such as SOA are often approached from a G-D orientation (Chen and Vargo, 2007). 


\section{Shifting to S-D logic based Design: New IS design challenges}

To chart the course toward a complete shift to S-D logic based design, we examine the design challenges that go beyond the traditional system development methods and scope in this section and looking fundamentally into the design thinking behind Design Science in Section 5.

As shown in the previous sections, S-D logic broadens the strategic orientation for firms and has the potential to influence IS design in a profound way, posing many design challenges. All FPs in S-D logic have implications on IS design. In particular, FP6, FP7, FP8, FP9 and FP10 of S-D logic have a direct impact on all phases of system development from requirements specification to implementation. System designers and IS researchers are challenged to develop new design methods from this S-D perspective.

FP6 (the customer is always a co-creator of value) challenges the theories and practice of system design by moving from viewing customers as external entities of the "system" to including customers as an integral part of the value co-creation service system. The view of the role of customers has also changed from static to dynamic, in both the IS design process and the use for IS once designed. The term "prosumer" (Toffler, 1980) (e.g., producer and consumer in one, in open source and social networking systems) describes the changing role of customers (Kazman and Chen, 2009). The close team assumption of traditional IS development methods is broken as the customers take active value co-creation role, such as in developing open source software, providing contents in social network sites and provide product reviews for commercial websites. In addition, in this context where customers' power is rising and their network effects broadened, the IS design will need to extend the traditional "one-to-one" (one firm to one customer) (Peppers and Rogers, 2004) customer modeling and analysis to "many-to- many" (many firms to many customers) (e.g., Gummesson, 2006), or network-with-network (Vargo and Lusch, 2004;2008) design, in which the firm's networks (including competitors) and the customers' networks are modeled and analyzed. This can be compared to the traditional design processes where customer needs are identified based on the static perspective of customers: the firm tries to "identify" known or latent needs and desires of customers through requirements solicitation techniques such as interviews, surveys and observations. Customers are then differentiated by needs and economic values. By contrast, S-D logic implies modeling both the customer's and the firm's competency and networks and the firm's competency and network to allow for dynamic service adaptation.

Importantly, in S-D logic, there is a distinction between co-production, which is common in current IS modeling methods, and co-creation concept regarding the customer's participation. Co-production refers to participation in the core good (if any): product "finishing", product/service design and development using lead users, existing product/service adaptation based on customer feedback, mass customization, open community ideation for product design and development (Woddruff and Flint, 2006). The role of customers is static and external to the system. Value-in-use and value-incontext captures the fact that value creation occurs as the customer integrates firm resources with personal and other marketfacing resources (FP9) and is therefore uniquely and experientially determined by the customer (FP10).

An S-D based design would challenge traditional system design in its need to deal with conflicting and unknown requirements, emergent system behaviors, continuous evolution of processes and contexts, changing resources in real time, and a fluid system boundary. It requires evolving from a system with a defined boundary (a firm) to a socio-technical ecosystem (Kazman and Chen, 2009; Vargo and Lusch, 2010), with multiple customers and multiple firms in 
dynamic and complex interaction. This requires an open, adaptive design methodology that is still in its infancy (Kazman and Chen, 2009).

FP7 (the enterprise cannot deliver value, but only offer value propositions) reemphasizes the value-in-use concept, which calls for a design that provides for dynamic value configuration (Stabelland and Fjeldstad, 1998) as a firm and its "supplier" resources are integrated with customers' resources, in the customer's context (value-in-context - see Vargo, et. al., 2008). This represents a major departure from traditional and existing IS design approaches, which were shown in the previous CRM and SCM examples.

FP8 (a service-centered view is inherently customer oriented and relational) punctuates the requirement of anchoring IS design in a relationship-development orientation. Nominally, this is the original root of CRM. However, the S-D perspective informs CRM to look beyond seeing a relationship as repeat patronage to seeing it as the core process in value creation (Vargo, 2009). Thus, the firms' value proposition is to become part of the customer's value creation. This implies that customers are not solely long term "brand" advocates but, more importantly, that the customer and the customer's networksincluding non-customers'-are co-creators of the brand (Merz, He, and Vargo 2009). This expanded notion of customer equity (as an advocate) needs to be captured in the system design. The design of traditional "loyalty" programs is typically limited to the purchase behavior of the customers based on patronage income, frequency, etc. S-D logic points toward promoting an enhanced form of word of mouth (Dellarocas, 2003), beyond advocacy, to include "acceptability" (e.g., of brand) and complementarity of resource.

FP9 (all social and economic actors are resource integrators) influences IS design to view the firm's value propositions in terms of operant resources, which serve as inputs for customers' value-creating processes through resource integration. That is, firm resources (including those created by integrating firm network resources) and customer resources are dynamically integrated by the customer with other customer-accessible resources to co-create value. Unanticipated service innovation is thus, not only possible, but likely. This extends the resource-advantage theory of competition (e.g., Hunt, 2004) beyond the firm's resources and requires arraying customer resources in the "value configuration." (Chen, 2008). This is considerably different from traditional design methods, which are often more goal-oriented and have a desired "state" of outcome, and challenges IS designers to model emergent outcomes.

Consistent with FP9, FP10 (value is always uniquely and phenomenologically determined by the beneficiary) implies the need for system evaluation measurement and metrics based on emergent concepts of value-in-use, rather than measurement/metrics based on predetermined value standards (e.g., disconfirmation models). That is, value is always idiosyncratically determined by the customer; it is experiential, contextual, and meaning-laden and requires metrics compatible with the phenomenological nature of co-created value. It thus suggests that system evaluation research need to be extended beyond static, one-time (snap-shot) of customer satisfaction and service quality measures. FP10 also suggests that the internal and external link between people, process and products/services must be integrated and adaptive to allow positive experience of dynamic value co-creation. People aspects including employee training or humanization or any technological use to simulate human interaction becomes ever critical in the S-D logic friendly IS development.

\section{S-D logic Implication for Design Science}

Addressing the aforementioned IS design challenges requires new models and new design thinking. The IS design challenges posited by S-D logic, such as open system to include customers as a co-creator, dynamic process of customers interaction for value 
co-creation, dynamic resource integration in the networks of networks context, and valuein-context or value-in-use, all points to the indeterminacy of the IS design problems and outcome measures. Requirements are not known a priori; design process are open; design outcome (value) can only be proposed (e.g., value proposition) but cannot be predetermined system; and many customer behaviors are emergent and unexpected. Kazman and Chen (2009), in proposing a Metropolis model, describe this new form of design/development, in contrast to traditional IS development, is more like designing/constructing a city than a building. That is, cities are not conceived or built by a single organization, have no centralized control, and are continuously evolving in a "perpetual beta" (O'Reilly, 2005) state.

The new design models or IT artifacts called for are at odds with the existing IS models in design science, which we argue are mostly approached from a G-D logic. Traditionally, IS designers are trained to focus on develop systems to support pre-determined "value propositions" or offering coming from the G-D logic of the firms instead of a broader, "value co-creation" logic. At best, "co-production" with customers has been considered in design methodologies such as JAD (Joint Application Design) and RAD (Rapid Application Development) in which customers' elusive requirements are solicited and modeled through an iterative design process that can incorporate customer feedback (Jaworski and Kohli, 2006). Recent development in agile methods, in which customers' feedback were incorporated iteratively in rapid requirement analysisdesign cycles, still, at best, is a co-production attempt -- customer participation in the development of a firm's offering.

As shown in past IS development discussed in Section 3, the design-science paradigm in IS has its roots in engineering and the sciences of the artificial (Simon, 1996). It is fundamentally a problem solving paradigm (Hevner, 2004). Grounded in the "bounded rationality" (Simon, 1996), it reflects a stronghold of G-D logic in the traditional system design and development practice in that it is based on closed system assumption and product focus. Customers are seen as external entity outside of the system. The problems definition and design process and outcome are viewed as deterministic or determinate. The traditional System Development Life Cycle (SDLC) (requirement analysis, design, implementation, testing) follows Simon's three stages in decision making: intelligence gathering, design (invent, develop, analysis), and choice. Often the requirements are solicited and defined, design choices are generated, prototyped and selected, then solution is implemented and tested. Evaluation results then can be used to provide feedback for the second round of design modification.

The design for new systems in new context and with new technological capabilities are what is considered indeterministic or wicked problems (Buchanan,1992; Brooks 1987, 1996; Rittel and Webber 1984)) and what design-science claims to be mainly interested in, rather than routine designs (Hevner et. al., 2004). Those problems are characterized by

- Unstable requirements and constraints based upon ill-defined environmental contexts.

- Complex interactions among subcomponents of the problem and its solution.

- Inherent flexibility to change design processes as well as design artifacts (i.e., malleable processes and artifacts).

- A critical dependence upon human cognitive abilities (e.g., creativity) to produce effective solutions.

- A critical dependence upon human social abilities (e.g., teamwork) to produce effective solutions.

However, the problem of approaching system design with bounded rationality perspective or deterministic view is that wicked problems in design science have been approached similarly to well-structured problems. (Kimbell and Street, 2009) "Bounded rationality" was a refutation of all the classic hypotheses of 
optimal choice: perfect knowledge of alternatives and consequences, perfect preferences between consequences and so on. Bounded rationality is an empiricallygrounded theory of human decision making and problem-solving based on "satisficing" principle. This principle introduces subjectivity, "rules of thumb," heuristics or ad hoc moves as basic decision-making processes for efficiency. Such efficiency is greatly needed in decision making and engineering (problem-solving) tasks and is a necessary condition but, we argue, is not sufficient for creative system design tasks for dynamically adaptive service systems.

The bounded rationality paradigm treating design as problem-solving activity, and thus may limit creativity in the design sense. S-D logic is consistent with the design thinking based on "expandable rationality" (Hatchuel, 2002) where problem-solving is only a moment within a design process.

There is a theoretical importance of distinguishing between design and problem solving.

Hatchuel (2002) has also explored the contribution that design can make to management and organization theory, arguing that design is essential to innovation and value creation.

The basic premises of expandable rationality are that 1) the design problems are wicked problem, 2) design problems are not knowable and evolve during the process, 3) a design attitude sees problems as opportunities for the invention of new alternatives, and 4) problem solving is a subset of innovative design. He shows that design requires expanding initial concepts, collective action and the creation of "learning devices." Hatchuel's definition of design involves the exploration of non-countable sets which are infinitely expandable.

There is at least one property that one expects from a consistent rationality concept in such context: to be expandable -- A capacity that is a necessary condition for any design process that we consider as a potential paradigm for economics of innovation and organization theory (Hatchuel,
2002; Kimbell and Street, 2009). This expandability of concepts underpins Hatchuel's formal theory of design (Hatchuel and Weil 2009) making it irreconcilable with earlier attempts rooted in bounded rationality (e.g. Simon 1996). In Hatchuel and Weil's (2009) concept-knowledge (C-K) theory, an important element of design activity is what you cannot (yet) know.

Consistent with S-D logic's conceptualization of customers being co-creators of value, implying that value is an emergent and contextual phenomenon, expandable rationality also captures the emergent characteristic 'client'-determined design outcomes. It suggests our design ability can be improved, by constructing new form of social interaction -- for example, involving users or other stakeholders in the design process (Hatchuel, 2002; Kimbell and Street, 2009) and crowdsourcing (Kazman and Chen, 2009).

The IS design challenges posited by S-D logic highlights the need for creativity in addressing the indeterminacy of the design problem and thus points to expandable rationality which is beyond just efficient, problem-solving paradigm. Furthermore, S-D logic informs a transformative design for the IS designer, based on adaptive and nonpredictive control. In the networks within networks context of service systems, the unanticipated innovation that the design brings may change the system's environment and the designers can transform current means into co-created goals with others (Sarasvathy et. al., 2008a). For example, the creation of the iPhone and its underlying platform changed the environment of the customers as well as the future service system design environment. A new service system (created by Apple) could be developed with iTune store partners, Apple brand followers, and other entities (e.g., application designers) as co-creators, bound by a common goal of innovative service provision with adaptive control. This adaptive control would be based on what the designers know and can do at a certain time (based on, for example, market snapshots, 
technology capabilities and other available information) but with no fixed, preconceived idea as to what the final design would be.

The design problem and solution then coevolve just as the design of the iPhone has co-evolved with its environment and cocreators. Sarasvathy et. al. (2008a; 2008b) called this effectuation logic. Facing uncertainly, goal ambiguity, and isotropy, effectuators act as though the environment were largely endogenous to their actions. While fully acknowledging external constraints on their actions, effectuators divide the event space into controllable and uncontrollable parts. They then focus on what they can control to reshape the environment. They do not assume opportunities to be preexistent in the environment; instead they seek to fabricate them. They also tend to ignore searching for pre-existent competitive threats, because they themselves do not know which markets or event spaces they will end up constructing. Organism and environment are inextricably intertwined in this worldview and the focus always is on creating new possibilities with extant means at any given instant. (Sarasvathy et. al. 2008a; 2008b)

Although the effectuation logic was presented in the organization design context, it fits well with the IS's and IS designer's role in a service system context. The principle of design science paradigm in IS research has traditionally been focusing on the interplay of IT strategy, business strategy, IT infrastructure and organizational infrastructure (Hevner, et.al. 2004). This interplay is becoming more crucial as information technologies are seen as enablers of business strategy and organizational infrastructure (Kalakota and Robinson 2001; Orlikowski and Barley 2001). Available and emerging IT capabilities are a significant factor in determining the strategies that guide an organization. A transformative design of service-oriented IS would align the IT capabilities to focus on the development of the organization's competency to provide better value proposition (e.g., control what they control) and enable the organization to build true relationship with customers and suppliers for value co-creation and service innovation (e.g., comfortable with the uncontrollable and unknown set). The learning mechanism is embedded in the system and the system would be able to adjust agilely to be dynamically adaptive to the changes required by the revised design. In this fashion, the design process never ends and there's coevolution of design problem and design solution. Design science is in need of models based on expandable rationality and transformative design thinking for effective service-oriented IS design.

\section{Conclusions}

This article contributes to make an explicit link between S-D logic and design science in order to advance service-oriented IS design which is characteriszed by the indeterminacy of the design problems and outcome measures. We show that the system design approached by G-D logic run the danger of rendering superficial attempts at relationship with customers in CRM applications and firm-centric value-adding activities rather than reciprocal, relationship building for value cocreation among partners and customers for effective service provision in SCM. To shift completely to S-D logic, many IS design challenges arise that called for new models or methods, including many-to-many customer modeling, open adaptive system design methods, and new system evaluation measures based on emergent concepts of value-in-use and value-in-context. To devise new service-oriented modeling, methods and evaluation measurement, S-D logic endorses a fundamental shift in design science's design thinking from bounded rationality for problem solving to expandable rationality for design for the unknown. Further suggested is a transformative IS design approach that combines expandable rationality and effectuation logic for organically, dynamically, adaptive, co-created service system design.

In essence, S-D logic informs Design Science to shift from G-D logic based methods to focus on new design thinking for designing new service-oriented methods that is inductive to innovation. In current service 
systems and networks-within-networks environment, opportunities for innovation abound. Every touch point with the customers in their networks and every interface between/among individual service systems in the value network is an opportunity for "open" innovation where value co-creation is essential. To embrace these opportunities and to effectuate innovation, IS

\section{References}

Brooks, F. P., Jr. (1996) "The Computer Scientist as Toolsmith II," Communications of the ACM , 39 (3), pp. 61-68.

Brooks, F. P., Jr. (1987) "No Silver Bullet: Essence and Accidents of Software Engineering," IEEE Computer, 20 (4), pp. 10-19.

Buchanan, R. (1992). Wicked problems in design thinking, Design Issues, 8 (2), pp. 5-21.

Chen, H-M. (2008). "Towards Service Engineering: Service Orientation and Business-IT Alignment," Proceedings of IEEE Hawaii International Conference on System Science (HICSS-41), Hawaii, Jan.7-10.

Chen H-M, Kazman R., and Perry O. (2010). "From Software Architecture Analysis to Service Engineering: An Empirical Study of Methodology Development for Enterprise SOA Implementation." IEEE Transaction on Services Computing, to appear, 2010

Chen, H-M and Vargo, S. (2007) "CRM and SOA: A Service-Logic Perspective," Proceedings of ICIS pre-conference workshop: Web-based E-Business (WEB07), Montreal, Canada, December 9, pp. 171-177.

Chen, H-M and Vargo S. L. (2008) "Toward An Alternate Logic for Electronic Customer Relationship Management." International Journal of Business Environment, 2 (2), pp. 116-132. designers will need to develop new design attitude that the unknown requirements and unexpected consequences of design are welcomed. By adopting a true serviceinnovation focus, perhaps IS education could be transformed to cultivate designers rather than simply engineering-oriented problemsolvers -- This will be a radical change to design science.

Chen, Q. and Chen, H-M. (2004) "Exploring the Success Factors of eCRM Strategies in Practice," Journal of Database Marketing and Customer Strategy Management, 11 (4), pp. 333343.

Checkland, P. and Holwell S. (1998/2005). Information, Systems, and Information Systems: Making Sense of the Field. Wiley, Chichester, UK.

Dellarocas, C. (2003) "The Digitization of Word of Mouth: Promise and Challenges of Online Feedback Mechanism," Management Science, 49 (10), pp. 1407-1424.

Gummesson, E. (2006) Many-to-Many Marketing as Grand Theory, Chapter 27 in The Service-Dominant Logic of Marketing, Lush R. F. and Vargo S. L., ed. M.E. Sharpe, Inc., New York.

Hart, M. L. (2006) "Customer Relationship Management: Are Software Applications Aligned with Business Objectives?" South African Journal of Business Management, 37 (2), pp.1732.

Hatchuel A. (2002) "Towards Design Theory and expandable rationality : The unfinished program of Herbert Simon." Journal of Management and Governance, 5 (3-4), pp. 260-273.

Hatchuel, A. and Weil, B. (2009) C-K Design Theory: An Advanced Formulation, Research in Engineering Design, 19, pp.181-192. 
Hevner A., March S.T., Park J., and Ram S. (2004) "Design Science in IS Research," MIS Quarterly, 28 (1), pp. 75-105.

Hunt, S. D. (2004) A General Theory of Competition: Resources, Competences, Productivity, and Economic Growth, Thousand Oaks, California: Sage Publications,

Jaworski B. and Kohli A. (2006) Co-creating the voice of the customer, Chapter 8 in The Service-Dominant Logic of Marketing, Lush R. F. and Vargo S. L., ed. M.E. Sharpe, Inc., New York,

Kalakota, R., and Robinson, M. (2001) EBusiness 2.0: Roadmap for Success, Addison-Wesley Pearson Education, Boston, MA.

Kale, S. H. (2004) "CRM Failure and the Seven Deadly Sins," Marketing Management, 13 (SeptemberOctober), pp. 42-46.

Kazman R. and Chen, H-M. (2009) "The Metropolis Model: A New Logic for the Development of Crowdsourced Systems," Communications of the ACM, 52 (7), pp. 76-84.

Kimbell L., Street P.E. (2009) "Beyond design thinking: Design-as-practice and designs-in-practice," CRESC Conference, Manchester.

Lusch, R., Vargo, S. L., \& Tanniru, M. (2010)," Service, Value Networks and Learning," Journal of the Academy of Marketing Science, 38 (1), pp. 19-31

Maglio P., Srinivasan S., Kreulen J., Spohrer J., "Service Systems, Service Scientists, SSME, and Innovation," Communications of the ACM, 49 (7), July 2006, 81-85.

Maglio, P. P. and Spohrer, J. (2008). "Fundamentals of Service science," Journal of the Academy of Marketing Science, 36 (1), 18-20.
Mentzer, J.T. et. al. (2001): "Defining Supply Chain Management," Journal of Business Logistics, 22 (2), pp. 1-25.

Merz, Michael, Yi He, and Stephen L Vargo (2009), "The Evolving Brand Logic: A Service-Dominant Logic Perspective," Journal of the Academy of Marketing Science, 37 (3), pp. 338-44.

Normann, R. (2001) Reframing Business: When the Map Changes the Landscape, Chichester, New Sussex: Wiley.

Orlikowski, W. J., and Barley, S. R. (2001) "Technology and Institutions: What Can Research on Information Technology and Research on Organizations Learn From Each Other?," MIS Quarterly, 25 (2), pp 145165.

O'Reilly, T. (2005). "What is Web 2.0? "Design Patterns and Business Models for the Next Generation of Software," http://www.oreillynet.com/pub/a/oreilly/ tim/news/2005/09/30/what-is-web20.html (Accessed: January, 2008)

Payne A. and Frow P. (2005) "A Strategic Framework for Customer Relationship Management," Journal of Marketing, 69 (4), pp. 167-176.

Peppers D. and Rogers M. (2004) Managing Customer Relationship: A Strategic Framework. Hoboken, New Jersey: John Wiley \& Sons, Inc.

Rittel, H. J., and Webber, M. M. (1984) "Planning Problems Are Wicked Problems," in Developments in Design Methodology, N. Cross (ed.), John Wiley \& Sons, New York, 1984.

Sameh, A-N,; Benbasat, I. (2009) "The Adoption and Use of IT Artifacts: A New Interaction-Centric Model for the Study of User-Artifact Relationships," Journal of the Association for Information Systems, 10 (9), pp. 661685 , 
Sarasvathy S.D., Dew N., Read S. and Wiltbank R. (2008a) "Designing Organizations that Design Environments: Lessons from Entrepreneurial Expertise," Organization Studies, 29 (3), pp.331350

Sarasvathy, S. D. (2008b). Effectuation: Elements of Entrepreneurial Expertise. Cheltenham, UK: Edward Elgar.

Simon, H. (1996). The Sciences of the Artificial. MIT Press, Cambridge.

Sisodia, R.S. and Wolfe, D.B. (2000) Information Technology: its Role in Building, Maintaining, and Enhancing Relationships, in Sheth, J.N. and Parvatiyar, A. (eds), Handbook of Relationship Marketing, Sage Publications, Thousand Oaks, CA, pp. 525-63.

Stabell, C. and Fjeldstad, O. (1998) "Configuring Value for Competitive Advantage: on Chains, Shops, and Networks." Strategic Management Journal, 19, pp. 413-437.

Toffler, A. (1980) The Third Wave. Bantam Books (USA).

Vargo, S. L. \& Lusch, R. F. (2004). "Evolving to a New Dominant Logic for Marketing," Journal of Marketing, 68 (1), pp. 1-17.
Vargo, S. L. and Lusch R. F. (2006) "ServiceDominant Logic: What It Is, What It Is Not, What It Might Be," in The Service-Dominant Logic of Marketing: Dialog, Debate and Directions, Robert F. Lusch and Stephen L. Vargo (eds.). Armonk, NY: M.E. Sharpe, Inc., pp. 43-56.

Vargo, S. L. \& Lusch, R. F. (2008). "ServiceDominant Logic: Continuing the Evolution," Journal of the Academy of Marketing Science, 36 (1), pp. 1-10.

Vargo, S. L. and Lusch R. F. (2011), "It's all B2B and Beyond...: Toward a System Perspective on the Market," Industrial Marketing Management, (forthcoming).

Vargo, S. L. (2009). "Toward a Transcending Conceptualization of Relationship: A service-dominant perspective," Journal of Business and Industrial Marketing, 24 (5/6), pp. 373-379.

Webster, F. J. (1992) "The Changing Role of Marketing in the Corporation," Journal of Marketing, 56 (October), pp. 1-17.

Woodruff R. B. and Flint, D. F. (2006) Marketing's Service Dominant Logic and Customer Value, Chapter 14 in The Service-Dominant Logic of Marketing, Lush R. F. and Vargo S. L., ed. M.E. Sharpe, Inc., New York.

Zuboff, S. and Maxmin J. (2002) The Support Economy, New York: Penguin. 


\section{About the Authors}

Hong-Mei Chen is a Professor of Information Technology Management at the Shidler College of Business, the University of Hawaii at Manoa and formally served as an Associate Dean for the College. She earned a Ph.D. in Business Administration (majoring in MIS, minor in Electrical and Computer Engineering) from the University of Arizona in Tucson. She conducts cross-disciplinary empirical research including service engineering, business-IT alignment, Electronic Customer Relationship Management, business intelligence, and multimedia distributed database systems. She was a Fulbright grantee and has directed several multi-million dollar, multi-institution research projects in high performance telemedicine, data mining and data warehousing. She has published in journals such as Communication of ACM, Journal of MIS, IEEE Transactions on Services Computing, Electronic Commerce Research, and other IS, computer science and software engineering journals.

Stephen L. Vargo is a Shidler Distinguished Professor at the University of Hawai'i at Manoa. His primary areas of research are marketing theory and thought and consumers' evaluative reference scales. He has had articles published in the Journal of Marketing, the Journal of the Academy of Marketing Science, the Journal of Service Research, the

Journal of Retailing, and other major marketing journals and serves on four editorial review boards, including the Journal of Marketing and the Journal of Service Research. Professor Vargo has been awarded the Harold $H$. Maynard Award by the American Marketing Association for "significant contribution to marketing theory and thought." 